\section{Polarography of Rare Elements}

Concerning Nuclear Industry

Teiichi Matsumae

Govn. Ind. Res. Inst., Nagoya

原子力の破究が盛んになるにつれて，原子炕 材としてのジルコニウム，原子然料としてのト リウムについての研究もまた多く行われるよう になつてきた。 それにつれて原材料中もしくは 製品中のジルコニウム，トリウムの分析法に関 する研究もいろい万と報告されている。元来IV $\mathrm{A}$ 属の元素はポーラログラフ的には必ずしも良 好な還元波を与えず,したがつてジルコニウム， トリウムの定量にはポーラログラフ分析法は余 り活用されていない，最近アゾ色素やニトロ化 合物等良好な還元波を与える有機試薬を用いる 間接的な定量法についてのいくつかの研究が報 告されている。乙れらについてその概略を約介 することにする。

\section{2. ジルコニウムのポーラログラフィー}

\section{1. Laubengayer $\cdot$ Eaton $の$ 研究}

Laubengayer Eaton ${ }^{1)} 0.1 \mathrm{~N}$ 㙫化カリウム 溶液に少量の塩酸を加えて $\mathrm{pH}$ 值を $2 \sim 5$ の籁 国に調節した溶液中で，ジコニウムの還元波 が得られることを報告している。

彼等は $0.1 \mathrm{~N}$ 塩化カリウム中で，才キシ塩化 ジルコニウムとして $1 \times 10^{-3} \mathrm{M}, 1 \times 10^{-3} \mathrm{M}$ 扎よ び $1 \times 10^{-4} \mathrm{M}$ のジルコニウムについて $\mathrm{pH}$ を 変化させて各々の場合に打ける岥電位之波高 とを測定した。その結果を表 1 に示したが，第 1 波はその波高が水素イオンの浱度に直接比例 することから，水素の還元によるものであるて と，第 2 波は $\mathrm{Zr}^{4+} \rightarrow \mathrm{Zr}^{0}$ の還元に相当するもの であることを結論している*。

第 2 波の半波電位としては，一定した值が得ら れず, $\mathrm{pH}$ が変化するに従つて変化し, 平均し

脚註 *最近この波はジルコニウムイオンの還元による ものでなく，水錯化合物からの水素の析泪によ るものであると啹贷されている、9
原子力に関係のある希元素の

$$
\text { ポーラログラフイー }
$$

松 前 鼎一

名古屋工業技術試験所

第 1 裴 ジルコニウムの半波電什

\begin{tabular}{|c|c|c|c|c|}
\hline & \multirow{2}{*}{ 電 解 液組 成 } & \multirow{2}{*}{$\mathrm{pH}$} & \multicolumn{2}{|c|}{ 半波電位 $\left(\begin{array}{l}\text { V } \\
\text { N.C.E. }\end{array}\right)$} \\
\hline & & & 第 1 波 & 第 2 波 \\
\hline 1 & $0.01 \mathrm{M} \mathrm{ZrOGl}{ }_{2}, 0.1$ & 2.03 & -1.667 & 洲定不能 \\
\hline 2 & NKGlに $0.1 \mathrm{MKOH}$ & 2.13 & -1.628 & 11 \\
\hline 3 & 者添加 & 2.28 & -1.660 & "I \\
\hline 4 & & 2.40 & -1.629 & $\prime \prime$ \\
\hline 5 & & 2.54 & -1.723 & $\prime \prime$ \\
\hline$\| \mathrm{A} 1$ & $0.01 \mathrm{M} \mathrm{ZrOGl}, 0.1 \mathrm{~N}$ & 2.96 & -1.548 & - \\
\hline 2 & $\mathrm{KCl} 0.01 \mathrm{MKOH}$ & 2.76 & -1.559 & - \\
\hline 3 & 添加 & 2.54 & -1.591 & - \\
\hline 4 & & 2.45 & -1.595 & 一 \\
\hline II $\mathrm{B} 1$ & $0.001 \mathrm{MZrOGl}_{2}, 0.1 \mathrm{~N}$ & 2.99 & -1.560 & -1.792 \\
\hline 2 & $\mathrm{KCl}$ 亿 $0.01 \mathrm{MKOH}$ & 3.18 & -1.533 & -1.740 \\
\hline 3 & を添加 & 3.33 & -1.520 & -1.742 \\
\hline 4 & & 3.56 & -1.512 & -1.683 \\
\hline 5 & & 3.66 & -1.511 & -1.682 \\
\hline 6 & & 3.82 & -1.529 & -1.577 \\
\hline 目 A 1 & $0.0001 \mathrm{MZrOCl}_{2}, 0.1 \mathrm{~N}$ & 4.05 & -1.560 & - \\
\hline 2 & $\mathrm{KCl}$ に $1.0 \mathrm{MKOH}$ & 3.28 & -1.609 & 一 \\
\hline 3 & 添加 & 2.86 & -1.628 & - \\
\hline III B 1 & $0.0001 \mathrm{MZrOGl}_{2}, 0.1 \mathrm{~N}$ & 4.02 & -1.567 & - \\
\hline 2 & $\mathrm{KCl} に 0.01 \mathrm{MKOH}$ & 4.40 & -1.518 & - \\
\hline 3 & 老添加 & 4.62 & -1.460 & - \\
\hline
\end{tabular}

て-1.689V.vs. (N.G.E.) を得ている. ての変 動はジルコニウムの加水分解もしくはジルコニ ウム錯イオンの性質の変化による。ジルコニウ ムイオンの濃度の変化に基因するものと考元ら れている。

ジルコニウムの测定しうる還元波を得るに は，それより正電仿に現われる大きな水素波を できるだけ抑え，しかもジルコニウムの加水分 解を防ぐために，水素イオン濃度を注意深く調 節することが必要である。 Laubengayer 等の 実験絬果から, $\mathrm{pH}$ が 3.5 前後, ジルコニウム の浱度1〜10 mil,M. 程度が最適之思才れ万。 


\section{2. Cozzi の研究}

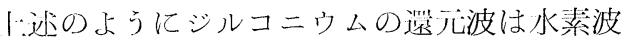
の影響を人きく受けるので，乙の影響をさける 污法が検傠されている。(Cozzi²)はメチレンブリ 二ーを添加するととによつて水素波を移動させ ている。乙の望会にも波高打よび岥電位は $\mathrm{pH}$ の変化とともに変動し, $\mathrm{pH} 3.2$ のさの 波高は全ジルコニウム濃度の $1 / 6$ に相当するに すぎないと述心゙ている。ててオキシ篮化ジル コニウム 2 モルに刘してフッ素イオンを 1 モル 添加するととによつてジルコニウムの波は完全 に㴥滅する。とのフツ素イオンの量はオキシフ ツ化ジルコニウム $\left(\mathrm{ZrOF}_{2}\right)$ を生成するに必要 な量の $1 / 4$ に過ぎないから，ジルコニウムの量 の3/4 は，急速に僈元性のイオンに変化するて とのできない非邉元性のコロイド状の形をとつ ているものと結論している。

\section{3. Colichmann, Ludewig の研究}

さらに Colichmann, Ludewig3)はメタノー ルを溶媒に用いて水素波の影響を除去してい る，彼等は塩化りチウムを支持電解質として， $5 \sim 0.5 \times 10^{-3} \mathrm{M}$ の濃度の硫酸ジルコニウム $\mathrm{Zr}$ $\left(\mathrm{SO}_{4}\right)_{2} \cdot 4 \mathrm{H}_{2} \mathrm{O}$, 打よびオキシ塩化ジルコニウム $\mathrm{ZrOCl}_{2} \cdot 8 \mathrm{H}_{2} \mathrm{O}$ について検討を行つている。 そ の絬果は表 2 に示した通りであつて, 硫酸ジル コニウムを用いた場合には， $-1.25 \mathrm{~V}$ ，打よび -1.56Vに波電位をもつ二つの波が得られ， オキシ㙫化ジコニウムの湯合には $-1.43 \mathrm{~V}$

符 2 表 メタノール中のポーラログラフ波

\begin{tabular}{|c|c|c|c|c|c|}
\hline 浱度 & \multicolumn{3}{|c|}{$\mathrm{Id} / \mathrm{C}(\mu \mathrm{A} \cdot / \mathrm{mM})$} & \multicolumn{2}{|c|}{$\begin{array}{c}\text { 半波電位 } \\
\text { (V vs. SCE) }\end{array}$} \\
\hline $\mathrm{M} \times 10^{-8}$ & 簢 1 波 & 簢 2 波 & 全波高 & 節 1 波 & 符 2 波 \\
\hline \multicolumn{6}{|l|}{$\mathrm{Zr}\left(\mathrm{SO}_{4}\right)_{2} \cdot 4 \mathrm{H}_{2} \mathrm{O}$} \\
\hline 5.0 & 5.6 & 1.6 & 7.2 & -1.25 & -1.56 \\
\hline 2.5 & 5.2 & 2.0 & 7.2 & -1.24 & -1.55 \\
\hline 1.0 & 3.7 & 3.4 & 7.1 & -1.25 & -1.55 \\
\hline 0.5 & 3.6 & 3.5 & 7.1 & -1.25 & -1.54 \\
\hline \multicolumn{6}{|l|}{$\mathrm{ZrOCl}_{2} \cdot 8 \mathrm{H}_{2} \mathrm{O}$} \\
\hline 5.0 & 6.0 & & & -1.43 & \\
\hline 2.5 & 5.6 & & & -1.41 & \\
\hline 1.0 & 5.0 & & & -1.39 & \\
\hline 0.5 & 4.0 & & & -1.37 & \\
\hline
\end{tabular}

- $1.37 \mathrm{~V}$ に帔電位をもつ一つの波が得られ る.

また各波の波高について Id/cを計算すると， 硫酸ジルコニウムの場合には全波高についての $\mathrm{Id} / \mathrm{c}$ はほぼ一定值をとり，ジルコニウムの濃度 が減小するに従つて第 1 波についての Id/c の 值は次第に減小し，第 2 波についてのそれは逆 に塯人する。そして $1 . \times 10^{-3} \mathrm{M}$ 以下では大体等

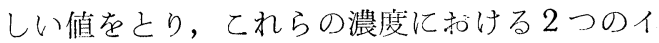
オン種は大体に㧈いて等量程度含まれていると 考えられる。

オキシ塩化ジルコニウムの湯合を硫酸ジルコ ニウム之同様に第 1 波についての $\mathrm{Id} / \mathrm{c}$ の值が オキシ塩化ジルコニウムの濃度の減小に従つて 減小する。

\section{3. 間接法によるジルコニウムのポーラ ログラフ的定量法}

前節に述べたようにジルコニウムを直接ポー ラログラフ法によつて定量しようとする方法 は必ずしも良好とは云えない。最近ポーラログ ラフ的に還元されかつジルコニウムと結合する 有機試楽, たと光ば $\mathrm{m}$-ニト口安急香酸, Mordant Blue 2R ¿しくはクッベロン等を用い, 閧接的にポーラログラフ法，電流滴定法によつ て定量する方法が報告されている。

\section{1. Mordant Blue 2 Rを用いる方法}

石憍, 藤永, 伊豆津 ${ }^{4)}$ はジーOーオキシアゾ色 素の Mordant Blue 2R〔MB 2 R〕を用いて 微量ジルコニウムの起量法について検討してい る。乙の方法は $\mathrm{pH}$ 約 $1.5 の$ 過塩素酸溶液中で, MB 2 Rがジルコニルイオンと定量的に反応し て，良好な 2 段のポーラログラフ波を生じ，そ の第 2 波の波高がジルコニルイオンの濃度に比 例するととにもと一ういている。

四 1 は $\mathrm{pH} 1.5$ の過塩䒺酸一過塩素酸ナトリ ウム溶液中にジルコニルイオンと過剩のMB 2 R之が存在する場合のポーラログラムである。 第 1 波は遊離のMB 2 Rのアゾ基の還光波で, 第 2 波はジルコニウムと結合したMB 2 Rの波 である。ジルコニウムの濃度が増加しても全波 高は僅かしか変化せず，第 1 波と第 2 波の波高 


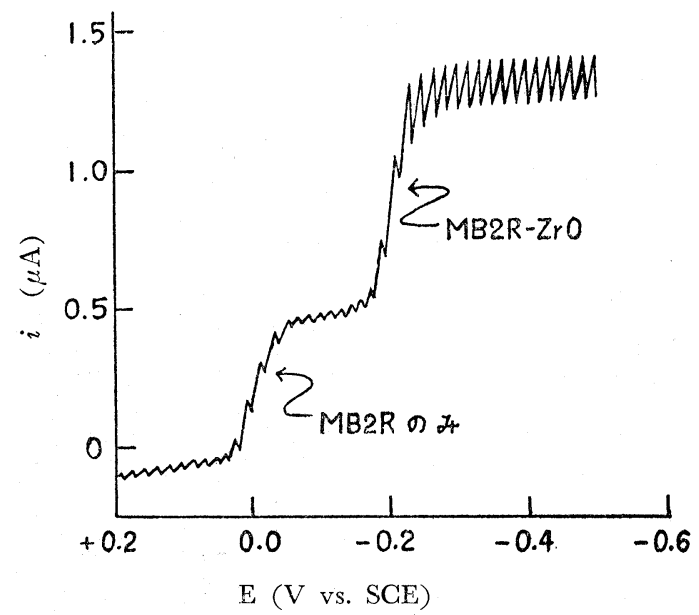

電解液組成： $7.76 \times 10^{-5} \mathrm{~mol} / l \mathrm{ZrO}^{2+}, 2.4 \times 10^{-4} \mathrm{~mol} / l$ $\mathrm{MB} 2 \mathrm{R}, 0.08 \mathrm{~N} \mathrm{NaClO}_{4}$ 打よび $\mathrm{HClO}_{4}(\mathrm{pH}$ 1.5)

図 1 電流電位曲線

（石機・藤永・伊豆津に上る）

の比率が変化する。しかし管 2 波の波高はジル コニルイオンの濃度に比例して增大する。 $\mathrm{pH}$

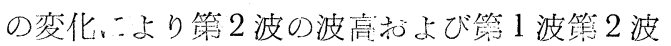
の半波電位は影響を受ける。節 2 波の波高は $\mathrm{pH} 1$ 以下および 2 以上で減少し, $\mathrm{pH} 1.2 \sim 1.7$ の間で尔ば一定值をとる。また将波電位は $\mathrm{pH}$ と直線関係にあり，節 1 波では $\mathrm{E}_{2}=+0.080$ $-0.059 \mathrm{pH}$ (V. vs. SCE), 篗 2 波では $\mathrm{E} \frac{1}{2}=$ $-0.100-0.065 \mathrm{pH}$ (V. vs. SGE) で表わさ れる。

第 2 波の波高とジルコニルイオンの濃度との 関係は表 3 に示すと打りであつて $2 \times 10^{-5} \sim 1.2$ $\times 10^{-4} \mathrm{M} / \mathrm{L}$ のジルコニルイオンを土 $3 \%$ 以内 の㖞差で定量することができる。

管 3 表 ジルコニウムの濃度と波高との關係

\begin{tabular}{|c|c|c|c|}
\hline $\begin{array}{c}\text { 濃 度 C } \\
(\mathrm{M} / \mathrm{L})\end{array}$ & $\begin{array}{c}\text { 波高 } \mathrm{i}_{\mathrm{d}} \\
(\mu \mathrm{A})\end{array}$ & $\begin{array}{c}\left(\mathrm{i}_{\mathrm{d}}-0.010\right) / \\
\mathrm{Cm}^{2 / 3} \mathrm{t}^{1 / 6}\end{array}$ & $\begin{array}{l}\text { 全 波高 } \\
\mathrm{i}_{\text {tota! }}(\mu \mathrm{A})\end{array}$ \\
\hline $0.78 \times 10^{-5}$ & 0.118 & 9.08 & 1.20 \\
\hline $1.55 \quad$ " & 0.179 & 8.07 & 1.24 \\
\hline $2.33 \quad$ & 0.270 & 8.81 & 1.25 \\
\hline $3.89 \quad 11$ & 0.414 & 8.58 & 1.24 \\
\hline 5.82 " & 0.603 & 8.58 & 1.23 \\
\hline $7.76 \quad 11$ & 0.793 & 8.62 & 1.21 \\
\hline $1.01 \times 10^{-4}$ & 1.002 & 8.47 & 1.20 \\
\hline $1.16 " \prime$ & 1.122 & 8.20 & 1.21 \\
\hline $1.20 \quad \prime \prime$ & 1.175 & 8.39 & 1.20 \\
\hline
\end{tabular}

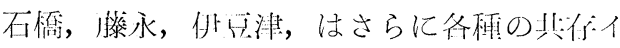
オンの影篦について検討し，マンデル陵を川い てジルコニウムを收害イオンから分晟し，MB 2 Rに上る筀量法として次の操作法を提唱して いる。

$10 \mathrm{ml}$ の嗃心分㒕管に $4 \mathrm{~N}$ 塩酸瞈性のジルコ ニルイオン溶液 $2.50 \mathrm{ml}(\mathrm{Zr}$ 濃度塂知，妨害イ オンを含む）を人れ，乙れに $1 \mathrm{M} / \mathrm{L}$ マンデル 酸溶液 $2.5 \mathrm{ml}$ を添加してかきまぜる、温浴中 にこの遠沈管を人れ，徐々に温度を上げて $85^{\circ} \mathrm{C}$ に30分間熱する。室温まで泠却後遠沈し上濯液 を捨てる。沈殿に温洗浄液 $1.5 \mathrm{ml}$ 加光てかき ませ遠沈して上澄液を除く。乙の洗浄操作をも う一度行つたのら，マンデル酸塩の沈殿を $2 \mathrm{~N}$ 水酸化ナトりウム $2.0 \mathrm{ml}$ で溶解し，かわりにシ ルコニウムの水酸化物を沈殿させる。漱時放置 したの占5 分閒遠沈し，上澄液を除き沈殿を水 酸化ナトリウム溶液で洗浄する。乙の操作によ りマンデル酸は除去されてジルコニウムの水酸 化物だけ残る。沈殿を $60 \%$ 過塩素酸 $0.5 \mathrm{ml}$ に上 かし， $25 \mathrm{ml}$ のメスフラスコ中に移す。 $2 \mathrm{~N}$ 水 酸化ナトリウム $1.0 \mathrm{ml}, 3.0 \times 10^{-3} \mathrm{M} / \mathrm{LMB} 2$ $\mathrm{R} 2.0 \mathrm{ml}$ を添加，標線まで希勫後， $70^{\circ} \sim 80^{\circ} \mathrm{C}$ に5 分閒熱して反応を完了さ些る。冷埥してホ ーラログラムを記録して第 2 波の波高を测这す る.

ての方法によつて妨害イオンの存在のいかん にかかォうらず，ジルコニウムが50１500r の筋

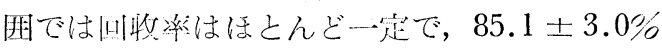
であつた。

\section{2. m-ニトロ安息香酸を用いる方法}

Graham 筞はマダネシウム合鉝非の1\%以 ドのジルコニウムを定量するのに次の上うな間

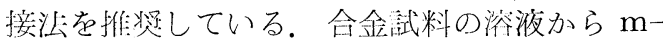
ニトロ'贷思否酸をもつてジルコニウムを沈殿さ せる，万别したの占沈殿を嫶酸に溶解し，沛貶 中でジルコニウムと結合していた $\mathrm{m}$ 一ニトロ疠 息否陵を嗔当な電解質湢淮を用いて，ポーラロ グラフ波を記録して定量するが炏にその操作汒 を詳しく述べる。

操作法 合金試料 $5 \mathrm{~g}$ を適当なビーカーに科 り取り，25ml の水を加えさらに $35 \mathrm{ml}$ の湍䃉

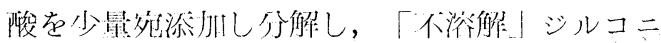


ウム之称される比較的僅かな量の残渣を万別す る. 残渣を $2.0 \mathrm{M}$ の硝酸で洗浄し, 口液と洗液 とを $250 \mathrm{ml}$ のメスフラスコに移す． $2.0 \mathrm{M}$ の 硝骖を用いて標線までうすぬ，よく混合してか らその $25 \mathrm{ml}$ をビーカーに分取する。乙れにア ンモニア水 $(1: 1)$ を水酸化ジルコニウムの沈 殿が生成しないように注意しながら，コンゴー レッドを指示楽として変出点に至るまで添加す る. 次に $20 \mathrm{ml}$ の $2.0 \mathrm{M}$ の塩睃, $10 \mathrm{~g}$ の硝酸ア ンモニウムを添加, 水を加えて $100 \mathrm{ml}$ とする. この溶液を沸とうさせかきまぜながら $\mathrm{m}$ 一ニト 口资息香酸の $1 \%$ 温水溶液 $100 \mathrm{ml}$ を添加する。 さらに5 分間ゆるやかに沸とうしたのちグーチ ルッボを用いろ別する。沈殿を熱湯で洗浄し, ルツボを沈殿とともにもとのビーカーに入れ, $6 \mathrm{~N}$ の塩酸 $25 \mathrm{ml}$ 加えて沈殿を加温溶解する. ルツボを取出し水で洗浄し，アンシニア水(1： 1) を加えコンゴーレッドの変色点まで中和し， 水で正確に $250 \mathrm{ml}$ にうすめる。 この $25 \mathrm{ml}$ を $100 \mathrm{ml}$ のスフラスコに分取し， $0.20 \mathrm{M} の$ 塩化 カリウム $50 \mathrm{ml}, 0.20 \mathrm{M}$ の塩酸 $10 \mathrm{ml}$, 打よび 極大抑制郕として $0.75 \%$ ○゙ラチン溶液 $1 \mathrm{ml}$ を添加し，水で漂線までうすめる。よく混合し その一部を電解セルにとり酸素を除去した後, ポーラログラムを記録し, 約一 $0.2 \mathrm{~V}(\mathrm{vs} . \mathrm{SC}$ E) に打ける第 1 波の波高を測定する。既知量 のジルコニウムについて上と同様の操作を行つ て子妰製した検量線（この検量線は少くとも $0 \sim 1.1 \times 10^{-4} \mathrm{M}$ の濃度崭囲で直線となる）と 刘比して，ジルコニウムの濃度を決定する。

この方法で $\mathrm{Ce}^{4+}$ はm-ニト口安息香酸と反応 して沈殿を生成するから妨害する。しかし $\mathrm{Ce}^{\mathrm{e}+}$ はこの試浆と反応しない，従つてセリウムを $1.5 \%$ 程度含有しているマグネシウム合金の場 命には，試料の溶解に硝酸の代りに塩酸を用い ると，セリウムは還元形のままに保たれる。

\section{3. クペロンによる電流滴定}

E. Olsenetal ${ }^{6)}$ はジルコニウムを10\%硫酸溶 液中でクペロンにより滴定する方法を報告して いるが，岡田・西等 ${ }^{7}$ はこの反応を微分ポーラ ワグラフィーを用いて検討して，ジルコニウム 晁流滴定法で定最している。
ジルコニウムは10\%硫酸溶液中では $\mathrm{Zr}\left(\mathrm{SO}_{4}\right)_{3}{ }^{2-}$ の形で存在するので

$$
\mathrm{Zr}\left(\mathrm{SO}_{4}\right)_{3}{ }^{2-}+4 \mathrm{Cupf}^{-}=\mathrm{Zr}(\mathrm{Cupf})_{4}+3 \mathrm{SO}_{4}{ }^{2-}
$$

の反応が期待されるが，滴定の备段階に抢いて ポーラ゙ログラムを記録し検討した結果，一0.84 $\mathrm{V}$ で拡散電流值を与えるものはクペロンでな く、兰種のクパロンとジルコニウムよりなる錯 化命物であるてとを明かにしている。

\section{4. トリウムのポーラログラフィー}

J. Masek ${ }^{\mathrm{s})}$ によるとトリウムはジルコニウム やベリリウム等と同じように，得られるポーラ ログラフ波はトリウムイオンから金属への邉元 によるものではなく，水錯化合物からの水素の 折州によつてあらわれるものであると云われて いる。ただジルコニウムとトリウムの違う点は トリウムの場合には 4 個の $\mathrm{H}^{+}$イオンが同じ電 位で幥元されず，別々に分離した波として得ら れる。従つてトリウム酸の-..つ一つの $\mathrm{H}^{+}$イオ ンの分離の速度諭を研究することが可能であ る.

また $\mathrm{NO}_{3}^{-}, \mathrm{NO}_{2}^{-}$がたとえばトリウムやラ ンタン等の多価陽イオンの共存の下で, 滴下水 銀電極で還元されるととはよく知られて打り"

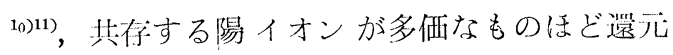
電位は陽性之なり，還元波の傾斜も大きくなる と云われている。乙の場合の還元反応は

$$
\begin{aligned}
& \mathrm{NO}_{3}{ }^{-}+8 \mathrm{e}+9 \mathrm{H}^{+} \rightarrow \mathrm{NH}_{3}+3 \mathrm{H}_{2} \mathrm{O} \\
& \mathrm{NO}_{2}{ }^{-}+6 \mathrm{e}+7 \mathrm{H}^{+} \rightarrow \mathrm{NH}_{3}+2 \mathrm{H}_{2} \mathrm{O}
\end{aligned}
$$

と推論されているが， $\mathrm{NO}_{\mathbf{n}}$-の僈元に関与する 電子数が多いから，波高は非常に高くしたがつ て感度は良好である。 Langer ${ }^{12)}$ はこの反心を 利用して䂺酸トリウムによるフッ素イオンの電 流滴定法を確玄している。

Komarek は溶液中の微量のトリウムを間接 的に定量する厅法について報告している ${ }^{13)}$. 卜 リウムを $\mathrm{Th}\left(\mathrm{IO}_{3}\right)_{4}$ として沈歓させ，乃别して 沈殿を水で数回洗浄する.沈殿を $0.1 \mathrm{M}$ の水酸 化ナトリウムで処理しトリウムの水酸化物に変 える、トリウムと結合していた沃素酸イオンの 濃度を塩化カリウム溶液を基礎液として，ポー ラログラフ的に決定して，トリウムの濃度を換 
算する。 Komarek はこの方法は $1 \mu \mathrm{g}$ 程度の卜

りウムを 2 〜\%程度の精度で定量しうると过 ベている.

また電流滴定法によつてトリウムを定量しよ うとする試みがなされている。 Smales, Airey 14) はモリブデン酸 アンモニウムを滴定液とし て，ウラニウム共存試料中のトリウムを定量す る方法について報告し, Gorden, Stine ${ }^{15)}$ は稀 土類元素と共存するトりウム，括よびモナズ石 中のトリウムの定量法として, Smales 等の方 法を改良している。ささらに Sundaresan, Kar khanavala $^{16)}$ の $0.2 \mathrm{M} フ ッ$ 化ナトリウムの標準 溶液で 0.6〜10 mg のトリウムを $0.001 \mathrm{M}$ 過 程素酸鉄（III）を指示萎として滴定する广法な どが挙げられる。

\section{参 考 文 献}

1) A.W. Laubengayer, A.B. Eaton, J. Am. Chem. Soc., 62, 2704 (1940).

2) D Cozzi, Proc. Intern. Cong. Pure and Applied Chem., I1, 57 (1947). C.A., 44, 6741 (1950).

3) E.L. Colichmann, W.H. Lndewig, Anal. Chem., 25, 1909 (1953).
4) 石橋，藤永，伊豆津，日化， $80 ， 628$ (1959)。

5) R.P. Graham et al., Canadian J. of Chem. 30, 10659 (1952).

6) E.C. Olsen; Anal. Chem., 26, 1747 (1954).

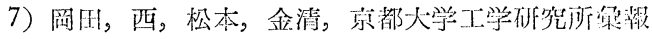
篻12輯，1 (昭和32年).

8) J. Masek ポーラログラフィー，6，14，(1958) 参照.

9) J. Heyrovsky, Actualites scientifiques et indus trielles No.90 (1933) Paris.

10) M. Tokuoka, Collection, 4., 444 (1932).

11) M. Tokuoka, J. Rüzicka, Collection, 6, 339 (1934)

12) A. Langer, Ind. Eng. Chem., Anal. Ed., 12, 511 (1940).

13) K. Komarek : Proc. Intern. Polarography Con gress, 1, 605. C.A., 4.5, 2818 (1951).

14) A.A. Smales, L. Airey : Atomic Energy Research Establishment, Harwell. Chemistry Division Memorandom, No. 131.

15) L. Gordon, C.R. Stine, Anal. Chem., 25, 192 (1953).

16) M. Sundaresan, M.D. Karkhanavala, Current Sci. (India), 23, 258 (1954). 